\title{
Article
}

\section{Fear of crime on the rail networks: Perceptions of the UK public and British Transport Police}

Power, Nicola, Mcmanus, Michelle Ann, Lynch, Rosa and Bonworth, James

Available at http://clok.uclan.ac.uk/18568/

Power, Nicola, Mcmanus, Michelle Ann ORCID: 0000-0002-0095-1071, Lynch, Rosa and Bonworth, James (2016) Fear of crime on the rail networks:

Perceptions of the UK public and British Transport Police. Crime Prevention and Community Safety, 18 (2). pp. 91-104. ISSN 1460-3780

It is advisable to refer to the publisher's version if you intend to cite from the work. http://dx.doi.org/10.1057/cpcs.2016.2

For more information about UCLan's research in this area go to http://www.uclan.ac.uk/researchgroups/ and search for <name of research Group>.

For information about Research generally at UCLan please go to http://www.uclan.ac.uk/research/

All outputs in CLoK are protected by Intellectual Property Rights law, including Copyright law. Copyright, IPR and Moral Rights for the works on this site are retained by the individual authors and/or other copyright owners. Terms and conditions for use of this material are defined in the policies page.

\section{CLoK}

Central Lancashire online Knowledge www.clok.uclan.ac.uk

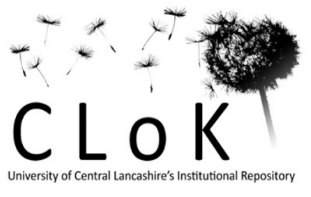




\title{
Fear of crime on the rail networks: Perceptions of the UK public and British Transport
}

\section{$\underline{\text { Police }}$}

\begin{abstract}
Counter-terrorism on the rail network is vital to the security of the UK. The British Transport Police (BTP) employ covert and overt security measures to prevent crime, which includes: closed circuit television, armed police, unarmed police, police community support officers, police dogs, stops and searches and awareness campaigns. All security measures aim to deter crime whilst importantly reassuring the public. We surveyed both members of the public and BTP officers about the perceived effectiveness of current security measures, specifically with regards to fear of terrorism. Feelings of reassurance and the perceived effectiveness of security measures were positively related. The most effective and reassuring security measure was the use of armed police; whereas the least effective and reassuring was the use of awareness campaigns. However, interestingly, qualitative analyses suggested that an increase in armed police without informed awareness campaigns would have a negative impact on public reassurance by increasing fear.
\end{abstract}

Keywords: Counter-terrorism; British Transport Police; Public Reassurance; Armed Police; Awareness Campaigns; Fear of crime 


\section{Introduction}

In the UK, 'terrorism' is an offence that involves the use or threat of violence or force, designed to intimidate the public or influence a government with the purpose of achieving a political, racial, religious or ideological cause (Terrorism Act, 2000). Although there is no universally and internationally accepted definition of terrorism (Townsend, 2011), the UK uses terrorism legislation such as Terrorism Act 2000 (Ss 54, 55) and Terrorism Act 2006 (Ss 1-8) to outline terrorism offences; which include the preparation for, the planning of, incitement or encouragement to commit acts of terrorism. Since 2000, the volume of terrorism legislation has increased alongside the growing threat of terrorism (Staniforth, 2001) both from international and domestic organisations (HM Government, 2011). The UK government regards terrorism as one of the highest priority risks and raised its terrorism risk register rating to 'severe' in August 2014; indicating that a terrorist attack on the UK is 'highly likely' (Home Office, 2014).

Although the chances of being victim to a terrorist attack in the UK are relatively small, fear of terrorism in the UK is much higher. Feelings of public safety are associated with increased public confidence in the police (HMIC, 2012) and so a key priority for policing is to ensure that 'fear of crime' is low. Research on fear of crime has identified how fear not only affects those who have been victim to criminal activity but also those who have not been directly exposed to crime (Warr, 2000); meaning that fear of crime is a psychological rather than objective measure. More recent advances on fear of crime research have highlighted variability in one's fear of crime based on the context-dependent characteristics of one's everyday environment (Solymosi, Bowers \& Fujiyama, 2015). For example, an individual may not fear being victim to a terrorist attack at home but may fear it when commuting to work; likewise they might not fear being robbed during their commute to work but fear burglary at home. Despite this, much research exploring fear of crime tends to 
view it as a holistic measure and there is relatively little research that investigates fear of terrorism directly, despite suggestions that people tend to overestimate both the risk of terrorism and their risk of being a victim of terrorism (Allouche \& Lind, 2010). Furthermore, it has been suggested that as terrorism is by definition an act to cause 'terror' in society, that the psychological fear of terrorism is incredibly important for the development of counterterrorism strategies (Braithewaite, 2013). This paper sought to address these gaps, by investigating the fear of terrorism specifically within the context of fear on the rail network.

\section{Policing and counter-terrorism on the rail network}

The UK's counter-terrorism 'CONTEST' strategy (2011) aims to, amongst other goals, reduce the vulnerability of the critical national infrastructure by increasing resilience in 'crowded places'. Recent devastating examples terrorist attacks in crowded places include the coordinated terrorist attacks that took place in Paris in November 2015, killing 130 civilians, and the 2013 Westgate Shopping Mall attacks in Nairobi, Kenya, killing 67 civilians. Although public places in general are at risk of terrorist attacks, the transport networks specifically (as a part of the critical national infrastructure) have also been targeted, such as the Tokyo subway sarin attack of 1995, the Madrid train bombings in 2004 and the 2005 London bombings. This paper was interested in investigating the UK public's perceptions with regards to fear of terrorism in the context of using the rail network.

The British Transport Police (BTP) are responsible for ensuring public safety and implementing security measures to minimise disruption and anticipate potential threats of terrorism on the railway (Railways and Transport Safety Act, 2003). As such, one of the key aims of the BTP is to provide a safe and secure railway, free from disruption and fear of crime (BTP Mission Statement; Railways Act, 1993). One way to reassure the public is to make security measures more visible; which can have the dual effect of both reassuring the 
public whilst deterring crime (Gore, 2012). Overt security measures used by the BTP include: CCTV, armed and unarmed police, PCSOs, canine explosive detection units and public awareness campaigns (BTP Specialist Units [no date]). Yet paradoxically, the police cannot disclose all of their security measures without risking vulnerability from terrorist attacks (Morral \& Jackson, 2009). These 'covert' methods can reduce public reassurance as they are not visible. Although the BTP acknowledges its use of covert non-visible methods (e.g. stop and searches, Counter-Terrorism Units), little is known about how these security measures interact with public reassurance. Interestingly, it has been suggested that increased exposure to counter-terrorist security measures specifically may in fact increase fear due to the irrational tendency for individuals to overestimate the likelihood of being victim to terrorist attacks (Braithwaite, 2013). This study sought to explore the relationship between perceived effectiveness of security measures and public reassurance against terrorism on the rail network more closely by surveying members of the public and BTP. This paper will briefly define each of the security measures that were examined; although it is worth noting that much of the available literature on deterrents relates to countering crime in general, rather than specific against terrorism.

\section{Closed Circuit Television (CCTV)}

CCTV is an effective and well utilised deterrent against crime in general as it is visible to potential criminals (Armitage, 2001) and can have a positive impact on public opinion (Honess \& Chapman, 1992; RSSB, 2011). CCTV dissuades individuals from committing crime due to the potential for video evidence, even when CCTV is functionally inoperative (Armitage, 2001). Arguably however, CCTV may have little impact on macrolevels of crime, as crime is simply displaced to areas without CCTV (Ratcliffe, Taniguchi \& Taylor, 2009) or may only deter specific types of crime (Gill \& Spriggs, 2005). Ratcliffe et al (2009) controlled for the effects of crime displacement, crime type and natural fluctuations in 
crime prevalence and indicated an overall $13 \%$ reduction in crime in areas with CCTV. However, the effects of CCTV on terrorism are less well defined, with warnings that it may actually encourage terrorists to target areas with CCTV if they seek mass media coverage for their cause (Stutzer \& Zehnder, 2013). Furthermore, it has been warned that CCTV may actually be counter-productive to feelings of public reassurance, as members of the public, particularly those from Muslim communities, feel that they are being spied upon and unjustly monitored by the Police and Government (Awan, 2011).

\section{Police: Armed Police, Unarmed Police and PCSOs}

The BTP are responsible for physically policing the railways with a mixture of armed police, unarmed police and PCSOs. The visibility of police officers is a key factor in the deterrence of crime (Simpson \& Cohen, 1988); as (potential) criminals are less likely to commit crime if there is a high likelihood that they will be caught in the act (Wright, 2010). It is also a key feature to support the UK's counter-terrorist CONTEST strategy (2011); specifically with regards to preventing terrorism (Lamb, 2013). Indeed, in direct response to the recent terrorist attacks in Paris (November, 2015), it was announced by the Commissioner of the Metropolitan Police, Sir Bernard Hogan-Howe, that the Home Office has pledged an extra $£ 34$ million to fund police firearms capacity and that London will train an extra 600 armed police officers as a counter-terrorist measure (BBC, January 2016). However, social work research on women in the Muslim community identified how visible policing can increase feelings of fear from potential insensitive and stigmatised policing practices (Guru, 2012). Armed police were first used on the rail network in February 2002 and provide day-today police patrol and resilience against potential terrorism and/or major incidents, with the aim to reassure the public via a visible armed presence and deter terrorism through an armed response (BTP Specialist Units [no date]). Although research exploring the police use of firearms in the UK is minimal, as the carrying of guns by the police is non-routine, research 
from America suggests that the police use of guns may counter-intuitively increase crime as the public have little confidence in repressive policing strategies in areas where gun use (by both the police and public) is high (Glebbeek, 2010). Police use of force has the potential to both increase and decrease public confidence, depending upon whether its use is viewed as legitimate and lawful, or illegitimate and unlawful (Kuhns \& Knutsson, 2010). Indeed many individuals, including police officers themselves, believe that the routine arming of police in the UK would undermine the police-public relationship (Orde, 2012). Yet, following recent rises in terrorism attacks and active shooter incidents, questions have been raised about whether the arming of police should be made routine (BBC, 2014). This study will help to unpack the relationship between fear of terrorism in the UK and the use of visible, armed and unarmed police.

\section{Police Dogs Unit}

The BTP has one of the largest Explosive Detection Dog Units in the country (BTP Media, 2013); which includes pro-active search dogs which sweep targeted areas for explosives, and passive explosive detection dogs monitoring the environment, crowd and luggage. Police dogs are valuable assets involved in all Counter Terrorism Patrols on the railways (Pastellas, 2013), because they are cost-effective, can outperform technology, and, if used correctly, can facilitate relationship-building with the public (Mesloh, 2006). Canine units are not only vital for the detection and deterrence of crime, but importantly facilitate public engagement and reassurance. However, very little academic research has been conducted into the interaction between the use police dogs and counter-terrorism. The limited studies to date have focussed how police dogs may injure police officers (Adedipe, Maher \& Strote, 2013) and differences in training styles for canine handlers (Mesloh, 2006). This gap in the literature emphasises the worth of research into perceptions of police dogs as a counterterrorist measure. 


\section{Stop and Search}

The use of 'stop and search' powers to counter terrorism allows BTP Officers to implement an 'unpredictable' security measure, which is likely to deter potential terrorists from both preparing and carrying out attacks (Morall \& Jackson, 2009). Stop and search powers heighten the public awareness of BTP presence, in turn reassuring their safety (BTP Specialist Units [no date]). Yet, due to the loose and unpredictable nature of stop and search powers, it has faced criticism from the media and members of the public, especially with ethnic minorities who felt subjected to 'hostile reconnaissance' (Borooah, 2011). The effectiveness of stop and search powers is dubious, for example, in 2010 there were 210,013 reported stop/searches of which only 9 resulted in arrest (0.004\%; Kirby, 2013). Research suggests that ethnic minority groups, particularly those who are Muslim, feel targeted by stop and search (Pantazis \& Pemberton, 2009). Muslim women feel fearful of stop and search due to the risk of their children being unjustly stopped (Guru, 2012). Despite rules having been made more stringent in recent years, the negative connotations they are associated with may threaten public feelings of reassurance, particularly among ethnic minorities (Moeckli, 2007; Parmar, 2011). Much of the recent academic research on stop and search has thus focussed on the detrimental impact on ethnic minorities, rather than levels of reassurance among the population as a whole. This study will address this gap by providing a more general perspective from the public on the use of stop and search powers as a counter-terrorist security measure.

\section{Awareness Campaigns}

Awareness campaigns are used by the BTP to target two very different audiences; potential offenders and potential victims. When campaigns are aimed at the public (potential victims) and kept general and non-specific, they have been found to be generally ineffective 
at reducing crime (Riley \& Mayhew, 1980); however, campaigns that provide specific advice for preventing a particular type of crime, relative to a particular location have been associated with significant crime reduction (Barth, 2006). This may be because the public are more informed about how to report crime, spot suspicious behaviour and avoid victimisation, and so awareness campaigns may facilitate community policing (Skogan \& Harnett, 1997). Indeed rail users felt more reassured against anti-social behaviour on the rail network following a targeted awareness campaign as they felt that anti-social behaviour was being addressed (RSSB, 2009). Victim focused campaigns also have the inadvertent benefit of deterring offenders, as they perceive crime to be more difficult as the public are more resilient (Laycock, 1991). Alternatively, campaigns specifically aimed at deterring offenders are most effective when they emphasise the certainty of arrest and punishment (Riley \& Mayhew, 1980), and, like victim focussed campaigns, when they are targeted towards specific crimes in specific locations (Laycock, 1991).

\section{Summary}

Public mass transit rail networks in the UK are an invaluable part of the critical national infrastructure. The number of rail users in the UK has more than doubled over the past 15 years, with the government investing a further $£ 16$ billion investment in the 'HS-2' rail network to link eight major cities in the UK by 2026 (Department for Transport, 2012). The UK is also facing one of its biggest challenges to date in the fight against terrorism (Home Office, 2014), with historic examples highlighting how the mass rail network is a key target for such atrocities. As public fear of terrorism is an important psychological consequence of terrorism (Braithewaite, 2013) it was important to investigate public perceptions relating to fear of terrorism on the rail network. Furthermore, as this study sought to provide recommendations with regards to 'what works' in terms of security measures that may decrease fear of terrorism, it sought to establish whether the current security measures 
implemented by BTP on the rail network were perceived to be effective and/or reassuring deterrents against terrorism by members of the public and BTP Officers. Using these findings, it will provide informed recommendations that may help to reduce fear ofterrorism on the rail network in the UK.

\section{Method}

\section{Participants}

Participants ( $\mathrm{n}=235)$ were split into two groups; 'public rail users' $(\mathrm{n}=154)$ or 'British Transport Police' (BTP) (n=81). Participants' ages ranged between 18 and 71 years $(M=$ 36.42 years, $S D=12.97)$, with $62.1 \%$ male $(n=146)$ and $37.4 \%$ female $(n=88)$. Public rail users were recruited from one of four major train stations in the UK (two in London; two in Northern England). They were approached at the station concourse and invited to complete a questionnaire. BTP participants were invited to complete the questionnaire during their working hours at one of three BTP police stations.

\section{Materials}

The questionnaire used in this study was constructed in liaison with a BTP representative. Questionnaires included open and closed questions to explore perceptions relating to terrorism, BTP security measures and perceived reassurance. Participants were asked these questions with regards to perceptions as a passenger on the rail network. Perceived effectiveness of security measures was measured by the question: 'How well do you think the presence of [CCTV/armed police/police dogs/stop and search/Unarmed police/ PCSOs/ Awareness campaigns] deters terrorism?' and scored from 1 (not at all) to 4 (very well). Feelings of reassurance were measured by: 'How reassured do you feel by the security measures stated below against terrorism?' and ranked their response from 1(less) to 5 
(more). Participants could provide further descriptive comments about these issues in an open text-box. Questionnaires had excellent (public group) and good (BTP group) validity using a Cronbach's Alpha test; scoring .923 and .82, respectively.

\section{Woolwich Attack}

During the time in which this study was conducted, a terrorist attack occurred in Woolwich, UK resulting in the murder of fusilier Lee Rigby (Morrison, Lansdown \& Pankhurst, 2013). Although there was no direct reference to this attack in the questionnaires and the attack did not take place on the rail network, questionnaires were coded as 'pre' and 'post' Woolwich attack. This was to make use of a unique opportunity to see whether public opinion and fear of crime changed immediately following a terrorist-related incident.

\section{Results}

\section{Perceived effectiveness and reassurance associated with security measures to deter terrorism}

The use of armed police was perceived to be the most effective security measure for deterring terrorism, with $84.3 \%$ of the total sample scoring it as 'well' or 'very well' as a method for deterring terrorism. This was followed by the use of police dogs (72.1\%), stop and search powers (70\%), CCTV (61.3\%), unarmed police (60.8\%), PCSOs (47.4\%) and awareness campaigns (36.1\%). Qualitative analyses of open-questions suggested this was driven by an overall desire for more visible policing on the railways: "More patrols on actual trains themselves; armed, un-armed and PCSO's walking through".

The use of police dogs had the greatest positive impact on feelings of reassurance with $81 \%$ of participants rating that they made them feel 'reassured' or 'very reassured'. This was followed by armed police (80.8\%), unarmed police (74.4\%), stop and search powers 
(73.9\%), CCTV (58.5\%), PCSOs (50.4\%) and awareness campaigns (36.5\%). BTP officers tended to favour the use of armed police: "Having a visible armed presence at X station would, in my opinion be a serious visible deterrent"; "We require more armed patrols at more locations", along with increased visible policing in general: "A visible police presence always reassures the public". The public also wanted an increase in armed police to deter terrorism: "I think they should have more armed police in public places", however this was somewhat diluted by fear that: "armed police increase risk of harm to innocents". A number of respondents commented on how increased visibility of armed patrols would increase fear as they associated their presence with unknown risk: "if I see armed police officers it makes me think there's an increased risk". Interestingly, although the public generally viewed awareness campaigns as ineffective against terrorism: "High profile campaigns are useful. But they won't deter the fanatical', they could be usefully adapted to reduce any counterproductive fears associated with other counter-terrorism measures, such as increased armed police: "The presence of armed police can be worrying, without explanation. An increase in awareness campaigns explaining that they are a security measure rather than a reactive measure would cause an increased feeling of safety”.

Overall, the use of armed police and police dogs were rated as the most effective and reassuring deterrents against terrorism, whereas the use of PCSOs and awareness campaigns were perceived as the least effective security measures (Figure 1). Perceived effectiveness of security measures was significantly and positive associated with feelings of reassurance against terrorism, $r h o=.515, p<.001$. BTP officers were additionally asked to think about how security measures influenced feelings of reassurance for the public. There was a significant and positive relationship between BTP officers' own perceived effectiveness of security measures and their judgements on public reassurance, rho $=.340, p<.005$. In terms 
of differences between groups of participants, BTP participants $(M=19.6, S D=4.93)$ perceived security measures to be significantly more effective at deterring terrorism than the public $(M=16.11, S D=5.24), \mathrm{t}(230)=-4.940, p<.00$, and were also significantly more reassured against terrorism $(M=20.4, S D=4.28)$ than the general public $(M=17.12, S D=$ $5.21), \mathrm{t}(233)=-4.856, p<.001$. The general public were additionally asked about how satisfied they felt with security on the rail network. Perceived satisfaction with security on the rail network was significantly and positive related to perceived reassurance against terrorism, $r h o=.226, p<.01$.

\section{Woolwich Attack}

During the period in which this study was being conducted, a terrorist attack occurred in Woolwich; although this incident did not occur on the rail network, it was a unique and unexpected opportunity to compare participant responses from before the attack $(37.45 \%$, $n=88)$ to those after the attack $(62.55 \%, n=147)$, to see how incidents of terrorism directly impact upon fear of terrorism. Those who were surveyed before the Woolwich attack were more reassured against terrorism $(M=19.09, S D=4.62)$, compared to those who were surveyed after the attack $(M=17.75, S D=5.38)$, and this was marginally significant, $\mathrm{t}(233)=$ $1.95, p=0.05$. Those surveyed before the Woolwich attack $(M=18.12, S D=5.42)$ also perceived deterrents as more effective than those after the attack $(M=16.87, S D=5.33)$, although this was non-significant, $\mathrm{t}(230)=1.709, p=.089$.

\section{Discussion}

Public confidence and a trusted relationship between the police and the public are important for community policing, as citizens must have faith that the police will protect society (Mesloh, 2006; Skogan \& Harnett, 1997). As such, ensuring that the public feel safe 
and reassured is a paramount responsibility of the police (HMIC, 2012). The use of armed police and police dogs were perceived to be the most effective and reassuring security measures against terrorism, compared to the use of awareness campaigns and PCSOs that were perceived as the least effective and reassuring. This study was the first of its kind to explicitly explore how specific security measures on the rail network interacted with public perceptions and fear of terrorism, thus providing a unique and practical contribution to the policing literature. Research on policing tactics has generally indicated that police use of force, either through firearms or canine patrols, can have a negative impact on public relations and reduce levels of trust with the public (Glebbeek, 2010; Orde, 2012). There has been recent debate in Scotland around the routine arming of police, which has received heavy criticism from the media, politicians and the public (BBC News, 2014). Yet the findings of the current study suggest the opposite effect; the public perceived the use of armed officers and police dogs as the most reassuring and effective tactics against terrorism. It will be interesting to continue monitoring this perception, especially with regards to fear of terrorism, following the recent announced increases in armed response units in the wake of the 2015 Paris terrorist attacks.

In explaining this unexpected finding, it is possible that the public perception of risk plays a role. Risk associated with terrorism may be deemed more extreme than threat associated with more general crime types, and thus the public become more accepting of increased police force. Indeed when proactive policing is perceived as legitimate by the public, then the public are more favourable in their judgements (Kuhns \& Knutsson, 2010). Perhaps public reassurance is substantially influenced by feelings of personal risk and vulnerability. It was also found in this study that members of the public who were surveyed before the Woolwich terrorist attack were more reassured than those who were surveyed after the attack. The prevalence of terrorism in the news, even though it was not specifically linked 
to the rail network, may have increased feelings of risk, which reduced feelings of reassurance.

Indeed, when individuals feel threatened, they are more likely to show harsh or extreme behaviour towards out-group members (Wohl, Squires \& Caouette, 2012), and so fears for risk of terrorism may have increased desire for police force. Finseraas and Listhaug (2013) found fear of terrorism increased in Western countries following the Mumbai attacks in 2008, and it has also been found that public threat perceptions with regards to terrorism are heavily influenced by the occurrence of mass-mediated threat messages by terrorist group leaders and by threat assessment alerts and announcements made by government (Nacos, Bloch-Elkon \& Shapiro, 2007). Thus the offence of terrorism appears to be a distinct and different type of criminal activity that the public may be more fearful of, perceive as higher risk, and thus desire increased levels of force to feel reassured. The use of PCSOs scored poorly in this study, which may be because the public perceive them as having restricted powers (Cosgrove \& Ramshaw, 2013) and so they are not seen as an extreme enough security measure against high risk terrorism. However, interestingly, it was found during the London 2012 Olympics that public feelings of safety were relatively high, despite the widespread media criticism of the security measures provided by G4S (George \& Mawby, 2015), suggesting that perceptions were not influenced by media coverage. It is possible that public desires for increased policing may not actually be related to a fear of terrorism, but a fear of crime in general. As data to empirically test how media reports of terrorism are hard to collect due to the unpredictable nature of when an attack may unfortunately occur, it is suggested that qualitative research to explore the factors that may increase or decrease fear of terrorism may be useful to unpack this relationship more fully. 
Although the public were in favour of more aggressive policing tactics, analyses of qualitative comments indicated that they also felt fearful when seeing armed police if they did not know why there was an increase in force (i.e., to deter terrorism). Previous literature has identified this whereby an increase in counter-terrorist security measures may increase fear of being victim to attacks (Braithwaite, 2013). It has been suggested that awareness campaigns can be effective crime deterrents, but only when offering specific information about crimes (Barth, 2006; Riley \& Mayhew, 1980) that can empower the public to spot and report criminal activity (Laycock, 1991). Interestingly, BTP officers did not anticipate potential fear as a result of increasing the number of armed officers on the rail network. It is possible that this is because BTP officers have a greater awareness and understanding of the training and expertise required of armed patrols and thus are better informed with greater confidence in their use. Indeed, public comments suggested a novel way to combine these two approaches, by proposing that the potential undesirable negative consequences that may arise from increased visible police force (i.e., fear) could be reduced by combining these security measures with public information campaigns to explain why the police were there (i.e., to deter terrorism). As such, an increase in armed police and canine units may facilitate public reassurance, but this must be caveated by transparent public messages that communicate the legitimacy and rationale of force.

\section{Conclusion}

This paper surveyed members of the public and the BTP to explore the perceived effectiveness of security measures used by the rail network to deter and reassure against terrorism. When individuals perceived measures to be effective deterrents, they also felt more reassured by them. Specifically, the use of armed officers and police dogs were perceived as the most effective deterrents, and were also more likely to be associated with feelings of 
reassurance; whereas the use of PCSOs and awareness campaigns were perceived as the least effective and reassuring. Qualitative comments supported these views and provided recommendations for how security measures may be combined. Indeed, it was suggested that although awareness campaigns were generally ineffective security measures, they may usefully reduce the potential fear associated with the increased use of armed police by helping to inform the public. It is thus recommended with the expected increase in the number of armed officers expected in the UK in response to the Paris terrorist attacks that an informed awareness campaign is provided, especially if additional armed officers are to be operational on the rail network.

\section{References}

Adedipe, A., Maher, P.J., \& Strote, J. (2012) Injuries associated with law enforcement use of force. Trauma. Vol 15, No. 2, pp 99-106.

Armitage R., (2002) To CCTV or to not CCTV? A Review of Current Research into the Effectiveness of CCTV Systems in Reducing Crime. NACRO Crime and Social Policy Report. London: NACRO.

Awan, I. (2011). COUNTERBLAST: Terror in the eye of the beholder: The 'spycam' saga: Counter-terrorism or counter productive? The Howard Journal, Vol. 50, No. 2, pp. 199-202.

Barth E. (2006) Crime Prevention Publicity Campaigns. Centre for Problem-Oriented Policing Response Guide, No.5.

BBC NEWS. (2005) London Bombers Staged 'Dummy Run' [Online] Available from: http://news.bbc.co.uk/1/hi/uk/4263176.stm [Accessed: 26th February 2013]. 
BBC NEWS (2014) Armed Police Scotland policy backed by independent report [Online] Available from: http://www.bbc.co.uk/news/uk-scotland-29787716 [Accessed 26th January 2015].

Berrebi C. (2009) The Economics of Terrorism and Counterterrorism: What Matters and Is Rational Choice Theory Helpful? In Davis, P \& Cragin, K. (eds.). Social Science for Counterterrorism: Putting the Pieces Together. Santa Monica, CA: RAND Corporation.

Borooah V.K. (2011) Racial Disparity in Police Stop and Searches in England and Wales. Journal of Quantitative Criminology, Vol. 27, No. 4, pp 453-473.

British Transport Police [no date]. Our Mission and Values [Online] Available from: http://www.btp.police.uk/about_us/our_vision,_mission_and_values.aspx [Accessed $18^{\text {th }}$ February 2013].

British Transport Police [no date]. Specialist Units [Online] Available from: http://www.btp.police.uk/about_us/our_people/specialist_units.aspx [Accessed 12th February 2015].

British Transport Police. (2007/08) Policing Plan North London 2007/08 [Online] Available from: http://www.btp.police.uk/pdf/LondonNorth-policing-plans-web-2007-08.pdf [Accessed 5th August 2013].

Caplan B. (2006) Terrorism: The Relevance of the Rational Choice Model. Public Choice, Vol. 128, No. 1-2, pp 91-107.

Cosgrove, F., \& Ramshaw P. (2013) It is what you do as well as the way you do it: the value and deployment of PCSO's in public engagement. Policing and Society: An International Journal of Research and Policy, Vol. 25, No. 1, pp 77-96. 
Department for Transport. (2012) Policy; Managing the Risk to Transport Networks from Terrorism and Other Crimes [Online]. Available from:

https://www.gov.uk/government/policies/managing-the-risk-to-transport-networksfrom-terrorism-and-other-crimes [Accessed $24^{\text {th }}$ February 2013].

Finseraas H., \& Listhaug, O. (2013) It can happen here: the impact of the Mumbai terror attacks on public opinion in Western Europe. Public Choice, Vol. 156, No. 1-2, pp 213-228.

Gill M., \& Spriggs, A. (2005). Assessing the Impact of CCTV. London, UK: Home office Research Study 292.

Glebbeek, M. L. (2010) ManoDura: Fighting crime, violence and insecurity with an iron fist in central America. In Kuhns, J. B., \& Knutsson, J. (eds.) Police Use of Force: A Global Perspective. Santa Barbara: Praeger.

Gore A. (2012) The Bear Facts- BTP London Paddington. BTP Newsletter [Online]. Available from: http://www.btp.police.uk/docs/newsletter/Paddington-NewsletterMay-2012.pdf [Accessed 12 ${ }^{\text {th }}$ August 2013].

Guru, S. (2012). Under siege: Families of counter-terrorism. British Journal of Social Work, Vol. 42, pp. 1151-1173.

HMIC. (2012) Narrowing the Gap-Police Visibility and Public Reassurance - Managing Public Expectation and Demand. London, UK: The Stationary Office.

HM Government. (2011) CONTEST: The United Kingdom's Strategy for Countering Terrorism. London, UK: The Stationary Office. 
Home Office. (2014) Threat-level from international terrorism increased [Online] Available from: https://www.gov.uk/government/news/threat-level-from-internationalterrorism-increased [Accessed 26th January 2015].

Honess T., \& Charman E. (1992) CCTV in Public Places: It's Acceptability and perceived effectiveness. London, UK: Crime Prevention Unit Series no. 35.

Jacobs B. (2010) Deterrence and Deterrability. American Society of Criminology, Vol. 48, No. 2, pp 417-441.

Kirby, S. (2013) Effective Policing? Implementation in Theory and Practice. London, UK: Pallgrave, Macmillan.

Kroenig M., \& Pavel B. (2012) How to Deter Terrorism. The Washington Quarterly Centre for Strategic and International Studies, Vol. 35, No. 2, pp 21-36.

Kuhns, J. B., \& Knutsson, J. (2010) Police Use of Force: A Global Perspective. Santa Barbara: Praeger.

Lamb, J.B. (2013). Preventing violent extremism; A policing case study of the west midlands. Policing, Vol. 7, No. 1, pp. 88-95.

Laycock G. (1991) Operation Identification, or the power of publicity? Security Journal, Vol. 2, No. 2, pp 67-72.

Mesloh, C. (2006) Barks or bites? The impact of training on police canine force outcomes. Police Practice and Research, Vol. 7, No. 4, pp 323-335.

Moeckli D. (2007) Stop and Search Under the Terrorism Act 2000: A Comment on R (Gillan) v Commissioner of Police for the Metropolis. The Modern Law Review, Vol. 70, No. 4, pp 659-670. 
Morral, A., \& Jackson, B. (2009) Understanding the role of deterrence in Counterterrorism Security. Santa Monica, CA: Occasional Paper RAND Homeland Security Programme.

Morrison A., Lansdown C. \& Pankhurst N. (2013) As it happened - Woolwich attack. BBC NEWS [Online] Available from: http://www.bbc.co.uk/news/uk-22630304 [Accessed: $1^{\text {st }}$ August 2013].

Nacos, B.L., Bloch-Elkon, Y., \& Shapiro, R.Y. (2007) Post 9/11 terrorism threats, new coverage and public perceptions in the United States. International Journal of Conflict and Violence, Vol. 1, No. 2, pp 105-126.

Orde, H. (2012). The British public would not trust or accept armed police [Online] The Guardian. Available from: http://www.theguardian.com/commentisfree/2012/sep/20/british-public-not-trustarmed-police [Accessed on 26th January 2015].

Pantazis, C., \& Pemberton, S. (2009) From the 'Old' to the 'New' Suspect Community: Examining the Impacts of Recent UK Counter Terrorist Legislation. British Journal of Criminology, Vol. 49, No. 5, pp 646-666.

Parmar, A. (2011) Stop search in London: Counter terrorist or counter productive? Policing \& Society, Vol 21, No. 4, pp 369-382.

Pastellas, A. (2013) Policing the Railways- Explosive Search Dogs. [Online] Available from: http://www.youtube.com/watch?feature=player_embedded\&v=1YON9XMg1-s [Accessed 20 $0^{\text {th }}$ February 2013].

Pogarsky, G. (2002) Identifying “deterrable” offenders: Implications for Research on Deterrence. Justice Quarterly, Vol. 19, No.3, pp. 431-452. 
RUNNING HEADER: FEAR OF CRIME ON THE RAIL NETWORK

Ratcliffe, J. (2006) Video Surveillance of Public Places. Centre for Problem-Oriented Policing Response Guide, No. 4.

Ratcliffe J., Taniguchi, T., \& Taylor, R.B. (2009) The Crime Reduction Effects of Public CCTV Cameras: A Multi-Method Spatial Approach. Justice Quarterly, Vol. 26, No. 4, pp. 746-770.

Railways Act (1993). London, UK: The Stationary Office.

Railways and Transport Safety Act (2003). London, UK: The Stationary Office.

Riley D. \& Mayhew P. (1980) Crime Prevention Publicity: An Assessment. London, UK: Home Office.

RSSB (2009). Trust and Respect: Facilitating shared expectations between passengers and front-line staff (T703 Report.) [Online] Available from: http://www.rssb.co.uk/pages/research-catalogue/pb009994.aspx [Accessed 18th August 2013].

RSSB (2011). Understanding the personal security issues on GB railways affecting multicultural groups (T891) [Online]. Available from: http://www.rssb.co.uk/pages/research-catalogue/t891.aspx [Accessed 19th August 2013].

Skogan, W., \& Hartnett, K. (1997) Community Policing Chicago Style. New York: Oxford University Press.

Staniforth A. (2010) Blackstone's Counter-Terrorism Handbook. London: Oxford University Press. 
Stutzer, A., \& Zehnder, M. (2013). Is camera surveillance an effective measure of counterterrorism? Defence and Peace Economics, Vol. 24, No. 1, pp. 1-14.

Terrorism Act (2000; 2006). London: The Stationary Office.

Tonry M. (2008) Learning from the Limitations of deterrence Research. Crime and Justice, Vol. 37, No. 1, pp. 279-311.

Townshend C. (2011) Terrorism: A Very Short Introduction. London: Oxford University Press.

von Hirsch, A., Bottoms, A., Burney, E., \& Wikstrom, P.O. (1999) Criminal Deterrence and Sentencing Severity: Analysis of Recent Research. London: University of Cambridge Press.

Wohl, M.J., Squires, E.C., \& Caouette, J. (2012) We were, we are, will we be? The social psychology of collective angst. Social Psychology and Personality Compass, Vol. 6, pp. 379-391.

Wright V. (2010) Deterrence in Criminal Justice-Evaluating Certainty vs. Severity of Punishment. Washington, DC: The Sentencing Project. 